\title{
Utilization of cytogenetic biomarkers as a tool for assessment of radiation injury and evaluation of radiomodulatory effects of various medicinal plants - a review
}

\author{
This article was published in the following Dove Press journal: \\ Drug Design, Development and Therapy \\ 25 September 2015 \\ Number of times this article has been viewed
}

\author{
Ravindra M Samarth ${ }^{1,2}$ \\ Meenakshi Samarth ${ }^{3}$ \\ Yoshihisa Matsumoto ${ }^{4}$ \\ 'Department of Research, Bhopal \\ Memorial Hospital and Research \\ Centre (ICMR), Bhopal, India; \\ ${ }^{2}$ National Institute for Research in \\ Environmental Health (NIREH), Indian \\ Council of Medical Research, Bhopal, \\ India; ${ }^{3}$ Department of Zoology, Centre \\ for Advanced Studies, University of \\ Rajasthan, Jaipur, India; ${ }^{4}$ Research \\ Laboratory for Nuclear Reactors, \\ Tokyo Institute of Technology, \\ Tokyo, Japan
}

\begin{abstract}
Systematic biological measurement of "cytogenetic endpoints" has helped phenomenally in assessment of risks associated with radiation exposure. There has been a surge in recent times for the usage of radioactive materials in health care, agriculture, industrial, and nuclear power sectors. The likelihood of radiation exposure from accidental or occupational means is always higher in an overburdened ecosystem that is continuously challenged to meet the population demands. Risks associated with radiation exposure in this era of modern industrial growth are minimal as international regulations for maintaining the safety standards are stringent and strictly adhered to, however, a recent disaster like "Fukushima" impels us to think beyond. The major objective of radiobiology is the development of an orally effective radio-modifier that provides protection from radiation exposure. Once available for mass usage, these compounds will not only be useful for providing selective protection against accidental and occupational radiation exposure but also help to permit use of higher doses of radiation during treatment of various malignancies curtailing unwarranted adverse effects imposed on normal tissues. Bio-active compounds isolated from natural sources enriched with antioxidants possess unique immunemodulating properties, thus providing a double edged benefit over synthetic radioprotectors. We aim to provide here a comprehensive overview of the various agents originating from plant sources that portrayed promising radioprotection in various experimental models with special emphasis on studies that used cytogenetic biomarkers. The agents will include crude extracts of various medicinal plants, purified fractions, and herbal preparations.
\end{abstract}

Keywords: cytogenetic biomarkers, medicinal plants, radioprotectors, radiation exposure

\section{Overview of radiation-induced cytogenetic damage}

Radiation is a form of energy that gets converted to other forms on absorption by matter thus resulting in cellular damage after exposure to radiation, however, the degree of damage is dependent on the nature and quality of radiation as well as the type of cells being exposed. Additional factors such as age, sex, and species of the animal also play a great role in variation in degree of radiation damage. In contrast to other forms of radiation, ionizing radiation has the capacity to break chemical bonds, impart energy to living cells through random interactions with atoms, giving rise to ions and reactive radicals, these in turn cause molecular changes that may lead ultimately to biological injury. Due to the high incidence of deaths resulting from exposure to high radiation doses, these effects are prominently analyzed qualitatively and quantitatively. However, harmful biological effects from low doses of radiation cannot easily be detected and analyzed. Moderate doses of radiation are known to increase the likelihood of cancer and birth defects.
Correspondence: Ravindra M Samarth Department of Research, Bhopal Memorial Hospital \& Research Centre (ICMR), Raisen Bypass Road, Bhopal462038, India

Email rmsamarth@yahoo.co.in 
Lower doses may cause temporary cellular changes, but higher doses have a higher incidence of causing abnormalities.

Manifestation of biological effects is preceded by physical and chemical changes caused due to radiation energy deposition in the living materials. Radiation can produce damaging effects by transferring its energy directly to the target molecules of the cells or by deposition of energy to the molecules of water present in surroundings. Radicals are more predominant in causing damage to biological systems since, cells and tissues consist of approximately $80 \%-90 \%$ water. ${ }^{1}$ The prominent effect of radiation is by the indirect action of free radical generation in water, which subsequently reacts with vital biological molecules producing a variety of consequences such as genetic effects, cell death, and carcinogenesis. $^{2}$

Ionizing radiation is an extremely competent potent cytotoxic mediator. It is expected that in cellular systems an X-ray dose of 1.5 Gy results in the production of $10^{-6}$ radicals. ${ }^{3}$ Ionizing radiation causes cell death by targeting DNA and thus DNA double-strand breaks are accountable for the damage. However, damage to other biological molecules apart from DNA has also shown potential for cell death. ${ }^{4}$ The structural aberrations can be produced in chromosomes by radiation at any stage of their mitotic cycle. When cells are irradiated just as they enter division, there is apparently some change in the surface properties of the chromosomes, which cause them to stick together. This stickiness has been attributed to a partial dissociation of the nucleoproteins and alterations in their pattern of organization. ${ }^{5}$ Thus, radiationinduced structural chromosomal aberrations are probably due to double-strand breaks. ${ }^{6,7}$

The radiation-induced double-strand breaks are found to be highly deleterious, interfering with transcription/replication leading to chromosomal rearrangements responsible for various types of cancers. ${ }^{8}$ The double-strand breaks get repaired by non-homologous end joining and homologous recombination repair mechanisms. ${ }^{9}$ The template for repair in homologous recombination repair mechanism is served by homologous chromosome. However, the non-homologous end joining mechanism is a major mechanism and involves several steps. The erroneous repair of double-strand breaks is the cause of cell death, genomic instability, and hereditary diseases including cancer.

\section{Available tools for assessment of radiation injury using cytogenetic biomarkers}

It is known that the medical use of low-dose ionizing has a high risk for causing cancer development and children are more prone to have such exposures. It has been observed that the somatic DNA was found to be damaged in subjects who received low doses of diagnostic X-rays. ${ }^{10}$ High-linear energy transfer (LET) radiation exposure during space travel or cancer therapy is more damaging than low-LET radiation and may result in cell inactivation, genetic mutations, cataracts, and cancer. However, these endpoints are interrelated to chromosomal damage and may be utilized as a biomarker for radiation-induced damage (Table 1).

\section{Conventional cytogenetic biomarkers}

For assessment of radiation exposure, biological dosimetry utilizing dicentric chromosomes analysis in human lymphocytes is a well-known method practiced since long ago along with physical dosimetry for radiation dose assessment in potentially overexposed people as well as for suspected exposures to estimate risk of health effects. ${ }^{11}$ Micronuclei, small satellite structures are the chromosomal fragments lacking centromeres. The frequency of micronuclei is also commonly used as a cytogenetic biomarker. Another cytogenetic endpoint, cytokinesis-block micronucleus assay, is considered to be simple in terms of scoring criteria as a reliable and sensitive cytogenetic biomarker. The premature chromosome condensations assay is also being used for biological dosimetry following radiation exposures. The main advantage of the premature chromosome condensations assay is that there is no need for cells to divide for evaluation of cytogenetic damage. ${ }^{12}$ Many authors have documented that cells exposed to radiation had significant increase in sister chromatid exchanges. The radiation had great capacity to induce DNA damage and form stable chromosomal aberration. For dose assessment translocations can be used as biological dosimetry.

\section{Molecular cytogenetic biomarkers}

A relatively new developed technique, fluorescence in situ hybridization, has revealed unique endpoints related to radiation quality. It has now become possible to detect interchromosomal and intra-chromosomal exchanges as well as distribution of the breakpoints of aberrations with the help of the mBAND technique. The cytokinesis-block micronucleus cytome assay is also being utilized to measure the cytogenetic damage induced by radiation. The single cell gel electrophoresis or comet assay, developed for the evaluation of DNA single-strand breaks, utilizes the DNA migration as a measure of the DNA damage, however, the DNA double-strand breaks can be measured by neutral comet assay. ${ }^{13}$ With the development of microarray formats, analysis of the chromosome damage of human peripheral lymphocytes is done with the modern technology of integration of techniques. ${ }^{14}$ The human 
Table I Tools for assessment of radiation injury using cytogenetic biomarkers

\begin{tabular}{|c|c|c|}
\hline Cytogenetic biomarkers & Particulars & References \\
\hline \multicolumn{3}{|c|}{ Conventional cytogenetic biomarkers } \\
\hline Total number of aberrations & $\begin{array}{l}\text { The radiation damage is quantified by scoring different types of chromosomal aberrations, } \\
\text { and is considered to be one of the accurate technique among cytogenetic tools used as } \\
\text { biological dosimeter. This technique is used to estimate the dose-response curves and is } \\
\text { also popular in radiation biology for radioprotective studies. }\end{array}$ & $82-89,160$ \\
\hline Dicentrics and ring chromosomes & $\begin{array}{l}\text { For assessment of radiation exposure, biological dosimetry utilizing dicentric chromosomes } \\
\text { analysis in human lymphocytes is a well-known method practiced since long ago, along with } \\
\text { physical dosimetry for radiation dose assessment in potentially overexposed people as well } \\
\text { as for suspected exposures to estimate risk of health effects. }\end{array}$ & $11,90-101$ \\
\hline $\begin{array}{l}\text { Micronuclei assay/cytokinesis-block } \\
\text { micronucleus assay }\end{array}$ & $\begin{array}{l}\text { Micronuclei, small satellite structures, are the chromosomal fragments lacking } \\
\text { centromeres. The frequency of micronuclei is variously used as cytogenetic biomarker. } \\
\text { The cytokinesis-block micronucleus assay is simple in terms of scoring criteria and is a } \\
\text { reliable and sensitive cytogenetic biomarker. }\end{array}$ & $102-117$ \\
\hline Sister chromatid exchanges & $\begin{array}{l}\text { Many authors have documented that cells exposed to radiation had significant increase in } \\
\text { sister chromatid exchanges. }\end{array}$ & $\begin{array}{l}87,88 \\
118,119\end{array}$ \\
\hline Translocations & $\begin{array}{l}\text { Irradiation causes various types of DNA damage that lead to stable chromosomal } \\
\text { aberration. Translocation chromosomal aberration is stable and can be used as biological } \\
\text { dosimetry for dose assessment. }\end{array}$ & $120-127$ \\
\hline $\begin{array}{l}\text { Premature chromosome } \\
\text { condensation }\end{array}$ & $\begin{array}{l}\text { The premature chromosome condensations assay is being used for biological dosimetry } \\
\text { following radiation exposures. The main advantage of the premature chromosome } \\
\text { condensations assay is that there is no need for cells to divide for evaluation of cytogenetic } \\
\text { damage. }\end{array}$ & $128-140$ \\
\hline \multicolumn{3}{|c|}{ Molecular cytogenetic biomarkers } \\
\hline $\begin{array}{l}\text { FISH/chromosome painting/mBAND } \\
\text { analysis }\end{array}$ & $\begin{array}{l}\text { A relatively newly developed technique, FISH has revealed unique endpoints related to } \\
\text { radiation quality. It has now become possible to detect inter-chromosomal and intra- } \\
\text { chromosomal exchanges as well as distribution of the breakpoints of aberrations with the } \\
\text { help of mBAND technique. }\end{array}$ & $\begin{array}{l}121,122 \\
141,142\end{array}$ \\
\hline DNA-PK & $\begin{array}{l}\text { Double-strand break repair pathways are responsible for maintaining genomic integrity, } \\
\text { genetic instability, and neoplastic transformation. It has been speculated that DNA-PK plays } \\
\text { an essential role in DNA double-strand break repair and maintaining genomic integrity. }\end{array}$ & $143-147$ \\
\hline $\begin{array}{l}\text { hTERT (telomerase reverse } \\
\text { transcriptase) and genomic instability }\end{array}$ & $\begin{array}{l}\text { The hTERT-immortalized cells have been found to be useful for determining the effects of } \\
\text { radiation. }\end{array}$ & $\begin{array}{l}|48-| 5 \mid \\
159\end{array}$ \\
\hline $\begin{array}{l}\text { Cytokinesis-block micronucleus } \\
\text { cytome assay }\end{array}$ & $\begin{array}{l}\text { Development of microarray formats analysis of the chromosomal damage of human } \\
\text { peripheral lymphocytes is done with the modern technology of integration of techniques. } \\
\text { The cytokinesis-block micronucleus cytome assay is being utilized as radiation biological } \\
\text { dosimetry specifically developed to assess various forms of chromosomal damage. }\end{array}$ & $10,152-155$ \\
\hline $\begin{array}{l}\text { The single cell gel electrophoresis } \\
\text { assay/comet assay }\end{array}$ & $\begin{array}{l}\text { The single cell gel electrophoresis or comet assay, developed for the evaluation of DNA } \\
\text { single-strand breaks utilizes DNA migration as a measure of the DNA damage, however, } \\
\text { the DNA double-strand breaks can be measured by neutral comet assay. }\end{array}$ & $\begin{array}{l}13,15,156 \\
157\end{array}$ \\
\hline
\end{tabular}

Abbreviations: FISH, fluorescence in situ hybridization; mBAND, high resolution multicolor chromosome banding.

telomerase reverse transcriptase (hTERT)-immortalized cells have been found to be useful for determination of the effects of radiation. Double-strand break (DSB) repair pathways are responsible for maintaining genomic integrity, genetic instability, and neoplastic transformation. It has been speculated that DNA-PK plays an essential role in DNA double-strand break repair and maintenance of genomic integrity.

\section{Modulation of radiation-induced cytogenetic damage by various medicinal plant products}

It is well-known that ionizing radiation damages DNA through direct and indirect action. In the direct mechanism, the DNA structure is altered due to disrupted chemical bonds, whereas in the indirect mechanism, DNA interacts with the reactive free radicals like ${ }^{\circ} \mathrm{OH},{ }^{\circ} \mathrm{H}$, and $e^{-}$aq generated by radiolysis of water. These reactive free radicals can be scavenged by compounds called scavengers thus having the ability to provide protection against damage caused by radiation. Therefore, it is of special interest to identify and develop effective agents which could be used for protection against radiation-induced genetic damage especially in humans. A series of chemicals like WR2721, WR1065, and S-(2-aminoethyl)isothiouronium bromide hydrobromide (AET) were studied but these chemical radioprotectors were found to have limitations in medicine due to their toxic side effects at effective doses. One of the avenues for non-toxic radioprotectors of plant origin has been explored 
in recent years, with the advantage of low or no toxicity at the effective doses.

\section{Radioprotective effects of medicinal plants}

Plant parts such as fruits, roots, stem/bark, leaves, and medicinal herbs have been found to have antioxidant capacity due to the presence of phenolic compounds, vitamins, nitrogen compounds, terpenoids, and other metabolites. These compounds have been shown to possess antioxidant, immunostimulatory, and antimicrobial activity and to impart radioprotective effects (Table 2). Several studies have focused on screening of herbal-/plant-based drugs for the development of drug discovery. ${ }^{16}$

\section{Adhatoda vasica}

The radiomodulatory effect of $A$. vasica extract was studied through chromosomal analysis in bone marrow as well as histological and biochemical alterations in testis of mice. ${ }^{17}$ A. vasica extract pretreatment was effective in increasing survival rate (dose reduction factor $[\mathrm{DRF}]=1.43$ ) and reducing cytogenetic damage in irradiated mice. Thus, $A$. vasica extract was found to possess radioprotective properties.

\section{Aegle marmelos}

The protective effects of $A$. marmelos extract against radiation were evaluated using micronucleus test. ${ }^{18,19}$ An increase in micronuclei frequency was noticed in an "irradiated alone" group while $A$. marmelos extract pretreatment was found to be effective in significantly reducing the cytogenetic damage in lymphocytes.

\section{Alstonia scholaris}

The cytogenetic alterations in mouse bone marrow were studied to assess the radioprotective effects of $A$. scholaris. ${ }^{20}$ Increased frequencies of dicentrics and chromosomal aberrations were reported after radiation exposure but $A$. scholaris bark extract pretreatment was effective in reducing the percentage of dicentrics and chromosomal exchanges significantly, thus providing evidence for radioprotective potential.

\section{Allium sativum (garlic)}

The extract of $A$. sativum was evaluated for its radioprotective effects in mice. ${ }^{21}$ The extract of $A$. sativum was found to be effective in significantly reducing the frequencies of radiationinduced micronucleated polychromatic erythrocytes. Also, different concentrations were studied against the clastogenic

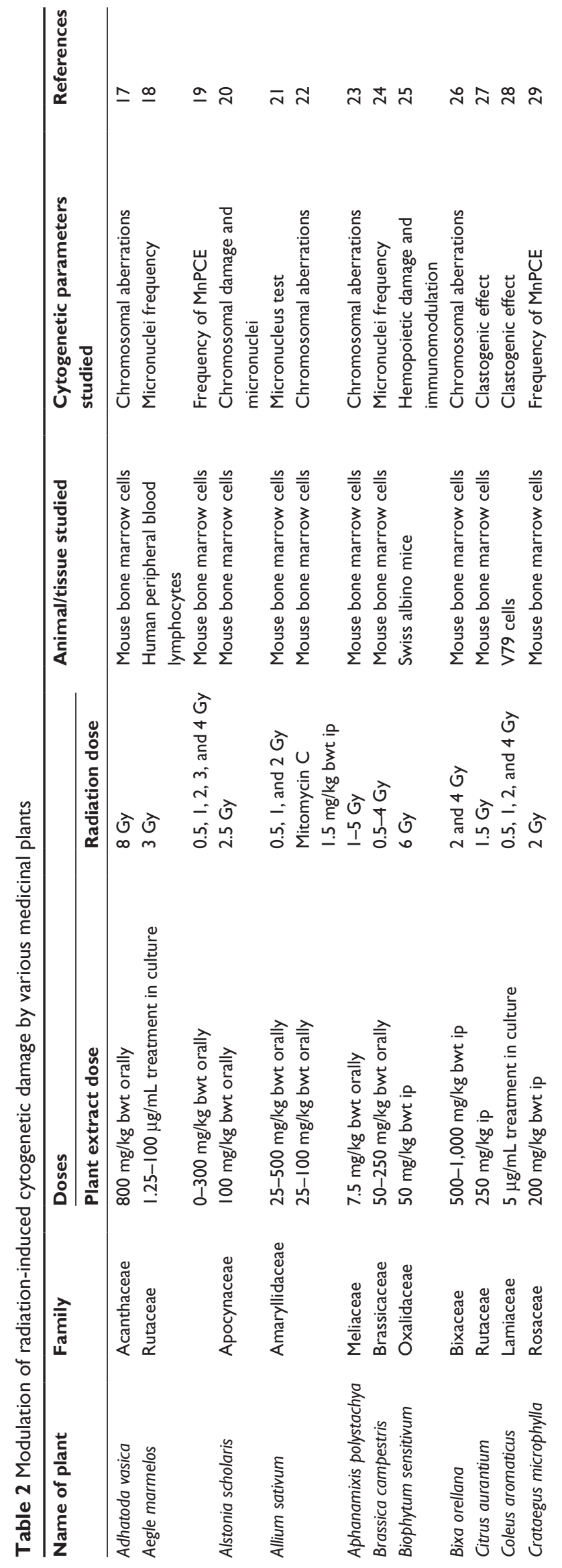




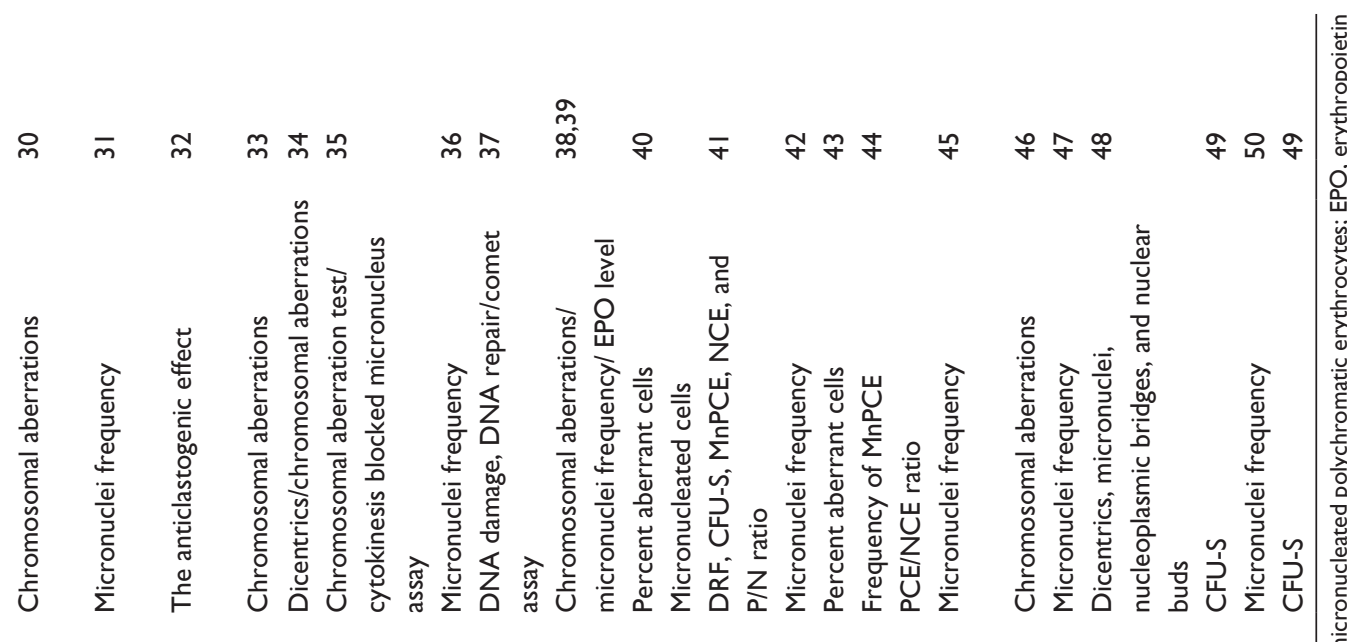

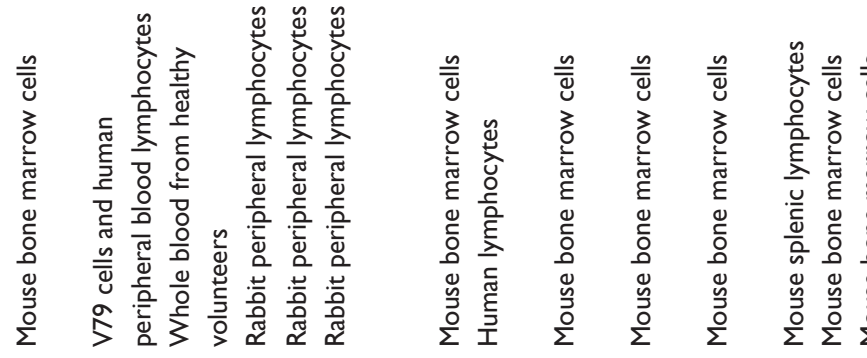

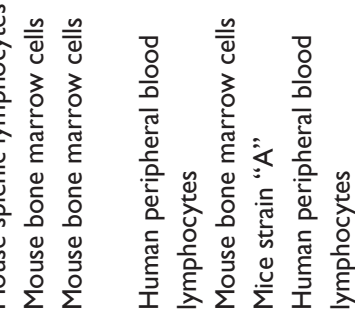

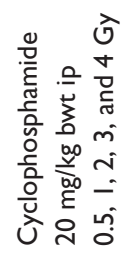

$\frac{\sqrt{2}}{\frac{0}{\pi}}$

命

ㅊํำ 전

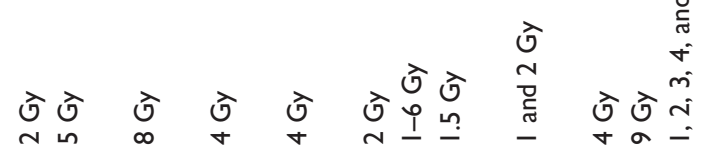

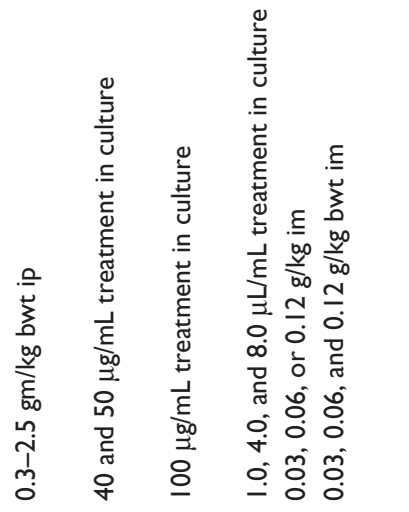

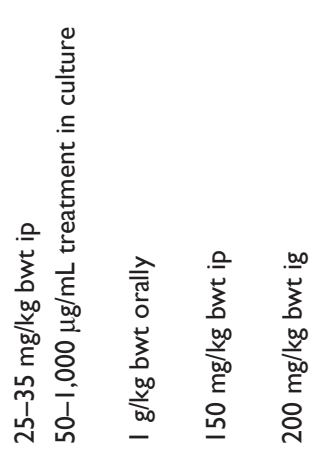

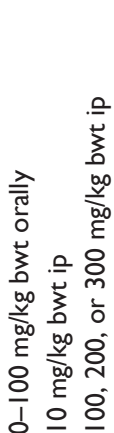

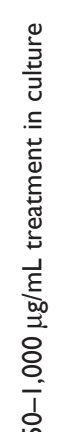

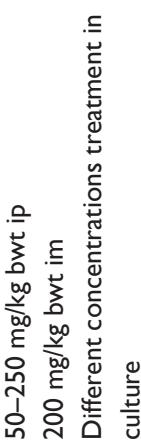

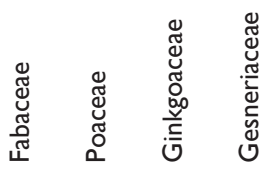

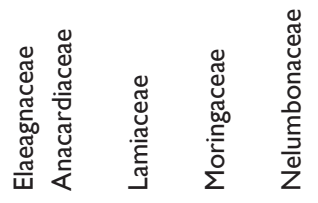

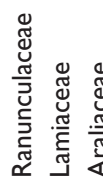

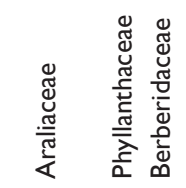

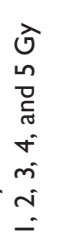
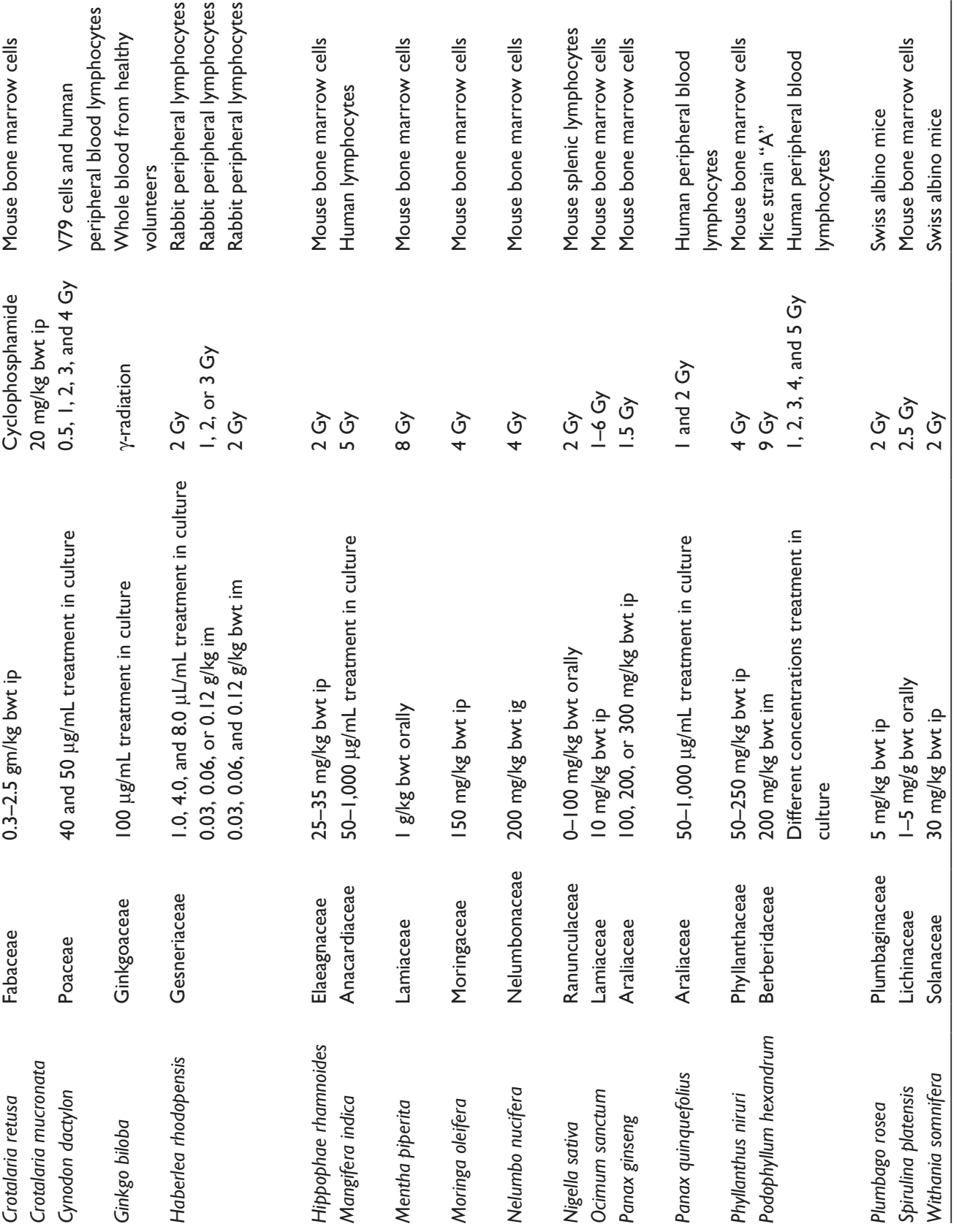

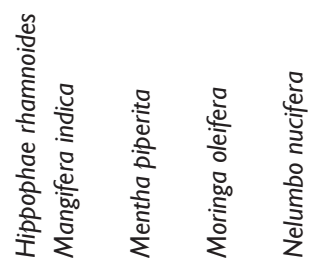

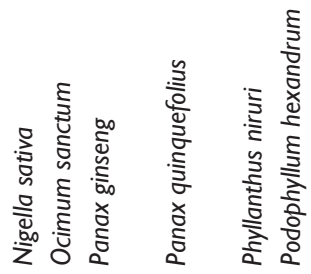

उิ 
effects of known toxicants. ${ }^{22}$ A dose-dependent effect on the frequencies of damaged cells and chromosomal aberrations was observed. It has been recommended that administration of the extract for 30 days is required for protection against the clastogenic effects of genotoxicants used in the study.

\section{Aphanamixis polystachya}

The radioprotection of mice by $A$. polystachya extract was studied using cytogenetic biomarkers. ${ }^{23}$ The study demonstrated that $A$. polystachya extract pretreatment resulted in a reduction of the cytogenetic damage in mice exposed to radiation.

\section{Brassica campestris}

The extract of B. campestris was found to be effective in protecting mice from chromosomal damage after irradiation. ${ }^{24}$ The $B$. campestris extract pretreatment effectively reduced the frequencies of micronuclei in irradiated mouse bone marrow. The protection afforded by $B$. campestris was due to its antioxidant capacity.

\section{Biophytum sensitivum}

The extract of B. sensitivum was evaluated to study radioprotection in mice. ${ }^{25}$ The animals pretreated with extract of B. sensitivum and exposed to radiation showed cytogenetic protection in terms of colony forming units in spleen (CFU-S) and immunomodulation was responsible for hematopoietic protection.

\section{Bixa orellana}

The radioprotective effects of $B$. orellana seed extract have been studied in mouse bone marrow through chromosomal aberration analysis. ${ }^{26} \mathrm{~B}$. orellana extract pretreatment was found to be effective in significantly reducing aberrant metaphases and chromosomal aberrations in irradiated mice.

\section{Citrus aurantium}

The protective effects of citrus extract against irradiation have been studied in mouse bone marrow. ${ }^{27}$ It was observed that citrus extract pretreatment greatly reduced the cytogenetic damage in bone marrow. It was speculated that the flavonoid contents of citrus extract may be responsible for the protective activity against irradiation in mice.

\section{Coleus aromaticus}

The extract of $C$. aromaticus was evaluated for its radioprotective effect in Chinese hamster fibroblast V79 cells. ${ }^{28}$ It was revealed that $C$. aromaticus extract treatment before irradiation offered significant protection from DNA damage induced by irradiation in terms of cytogenetic biomarkers.

\section{Crataegus microphylla}

The extract of C. microphylla (hawthorn) was studied for radiation-induced genotoxicity in mouse bone marrow cells. ${ }^{29}$ Administration of hawthorn extract before irradiation showed significant reduction in micronucleated polychromatic erythrocyte frequency in bone marrow cells of mice. It was speculated that radioprotection offered by hawthorn extract could be due to its antioxidant activity that helps in reducing the radiation-induced genotoxicity in mice.

\section{Crotalaria retusa and Crotalaria mucronata}

The extracts from C.retusa and C. mucronata were evaluated for their anticlastogenic effects against irradiation in mice. ${ }^{30}$ The study showed that fruit extract of $C$. retusa caused a dosedependent increase in chromosomal aberration frequency in mouse bone marrow. The clastogenic effect of $C$. retusa fruit extracts in mouse bone marrow cells was attributed to the alkaloids.

\section{Cynodon dactylon}

The radiomodulatory potential of $C$. dactylon extract was studied. ${ }^{31}$ A significant reduction in micronucleated binucleated cells was observed in C. dactylon extract pretreated irradiated V79 cells and lymphocytes. Also, C. dactylon extract pretreatment resulted in the significant reduction of percentage of micronucleated binucleated cells. Thus, the radioprotective effect of C. dactylon has been demonstrated.

\section{Ginkgo biloba}

The G. biloba extract was evaluated for its anticlastogenic activity. ${ }^{32}$ It has been demonstrated that clastogenic factors in the blood showed significant reduction after treatment of G. biloba extract for 60 days.

\section{Haberlea rhodopensis}

The radiomodulatory effect of $H$. rhodopensis extract was studied against gamma irradiation in peripheral blood lymphocytes of rabbits. ${ }^{33}$ It has been demonstrated that $H$. rhodopensis extract pretreatment was useful in reducing radiation-induced cytogenetic damage. Further it was demonstrated that the radioprotective as well as antioxidant potential of $H$. rhodopensis in rabbits suggested the need of in-depth investigations for identification of the protective compounds. ${ }^{34}$ The different concentrations of $H$. rhodopensis extract were injected into rabbits. The rabbits were exposed to 
gamma-radiation, which showed dose-dependent reduction in frequency of chromosomal aberrations and micronuclei. ${ }^{35}$

\section{Hippophae rhamnoides}

The protective effect of $H$. rhamnoides extract against radiation-induced cytogenetic damage was studied in mice. ${ }^{36}$ The H. rhodopensis extract treatment increased the survival rate in irradiated mice. It was observed that administration of $H$. rhamnoides alone did not enhance the micronuclei frequency but showed a dose-dependent decrease in micronuclei frequency in pretreated irradiated mice, thus protecting against radiation-induced cytogenetic damage.

\section{Mangifera indica}

The $M$. indica extract was studied for evaluation of radioprotection in human peripheral blood lymphocytes and lymphoblastoid cells. ${ }^{37}$ Dose-dependent DNA damage was observed after $M$. indica extract treatment in human peripheral blood lymphocytes and lymphoblastoid cells, without altering the DNA repair capacity.

\section{Mentha piperita}

Administration of M. piperita extract before radiation exposure in mice was found to provide protection in bone marrow cells. ${ }^{38}$ Pretreatment with $M$. piperita extract significantly reduced the number of aberrant cells and different chromosomal aberrations in irradiated mice. Also, M. piperita extract pretreatment was found to be effective in protecting against hematopoietic damage in bone marrow of irradiated mice by maintaining the erythropoietin level..$^{39}$

\section{Moringa oleifera}

The radioprotective property of $M$. oleifera extract in mice has been studied. ${ }^{40} \mathrm{~A}$ significantly reduced number of micronuclei and aberrant cells in M. oleifera extract pretreated irradiated animals was reported. However, fractionated administration of $M$. oleifera extract offered more protection in terms of survival of animals and chromosomal damage in bone marrow cells.

\section{Nelumbo nucifera}

Pretreatment with $N$. nucifera extract has been shown to provide protection against sickness and mortality in mice exposed to radiation. ${ }^{41}$ It was observed that $N$. nucifera extract effectively maintained spleen index and stimulated endogenous spleen colony forming units in mice. Also, a significant reduction in cytogenetic damage was noticed in bone marrow cells of $N$. nucifera extract pretreated irradiated animals.

\section{Nigella sativa}

The extract of $N$. sativa was studied in mice to evaluate its protection against radiation damage. ${ }^{42}$ It was observed that $N$. sativa extract pretreatment resulted in significant reduction in lipid peroxidation and intracellular reactive oxygen species in splenocytes. Also it was reported that N. sativa extract pretreatment increased the survival rate of irradiated animals indicating the radioprotective ability of $N$. sativa.

\section{Ocimum sanctum}

Chromosomal aberration analysis was carried out in mice to evaluate the radiation protective property of extract of $O$. sanctum..$^{43}$ The pretreatment of mice with extract of $O$. sanctum provided faster recovery and helped in removal of aberration from the cell. It was found that extract of $O$. sanctum afforded in vivo protection against radiation and suggested free radical scavenging as a probable mechanism for radioprotection.

\section{Panax ginseng}

The radioprotective effect of $P$. ginseng extract (ginsan) was evaluated in bone marrow cells of mice. ${ }^{44}$ It has been shown that ginsan pre- or post-treatment resulted in a significant dose-dependent increase in frequency of micronucleated polychromatic erythrocytes in bone marrow cells, thus reducing radiation injury in mice.

\section{Panax quinquefolius}

The extract of $P$. quinquefolius has been studied for its radioprotective potential on human peripheral lymphocytes through cytogenetic biomarkers. ${ }^{45}$ It has been observed that ginseng extract treatment resulted in concentrationdependent declined micronuclei yield in lymphocytes. Therefore, ginseng extract is considered to be a non-toxic natural product for dietary supplements as countermeasure for radiation risk.

\section{Phyllanthus niruri}

The extract of $P$. niruri has been evaluated in mouse bone marrow through chromosomal aberration analysis. ${ }^{46}$ It was noticed that administration of extract of $P$. niruri caused a significant decrease in chromosomal aberrations in irradiated mice.

\section{Podophyllum hexandrum}

The extract of $P$. hexandrum was evaluated for its radioprotective effects in mice. ${ }^{47,48}$ The studies showed that $P$. hexandrum provided cytogenetic protection in terms of 
decreased radiation-induced micronuclei frequency and chromosomal aberrations in mouse bone marrow.

\section{Spirulina platensis}

Administration of extract of $S$. platensis before radiation exposure has shown significant protection in mouse bone marrow cells. ${ }^{50}$ It has been reported that $S$. platensis extract treatment reduced micronuclei frequency significantly in irradiated mice.

\section{Withania somnifera and Plumbago rosea}

The extracts of $W$. somnifera and $P$. rosea were studied for their effects on tumors. ${ }^{49}$ It was observed that extracts of $W$. somnifera and $P$. rosea had significantly reduced the CFU-S. Further these results have revealed that the effects of extracts of $W$. somnifera and $P$. rosea were radiosensitizing and tumor non-specific in nature.

\section{Radioprotective effects of certain phytochemicals}

It has been revealed that chromosomal aberrations are formed by interaction of free radicals with DNA and cause cytogenetic damage (Table 3). Such damage can be reduced significantly by agents that scavenge the free radicals, which are called antioxidants. Radiation is responsible for the production of free radicals in cells, therefore, this damage can be minimized by antioxidants. Plants are abundantly available and contain a variety of flavonoids with antioxidant capacity and have become the prime focus of research in recent years in order to develop an effective radioprotector for use in the medical field. Therefore, researchers gained momentum to work for active principles of plants and isolated compounds. Also, it was more convenient, as it greatly reduced the amount to use, and determined the possible mechanisms involved in radioprotection at a cellular level.

\section{Apigenin}

Apigenin was evaluated for radioprotective effects on cell cultures exposed to radiation and showed a significant dosedependent elevation in the number of micronuclei, it was speculated that apigenin may further be studied to illustrate its possible role as promising radioprotective drug. ${ }^{51}$

\section{Beta carotene}

The radiation-induced cytogenetic damage in bone marrow of mice after beta carotene administration was evaluated by micronucleus test. ${ }^{55,161,163,164}$ It has been demonstrated that a significant decline in the number of micronucleated

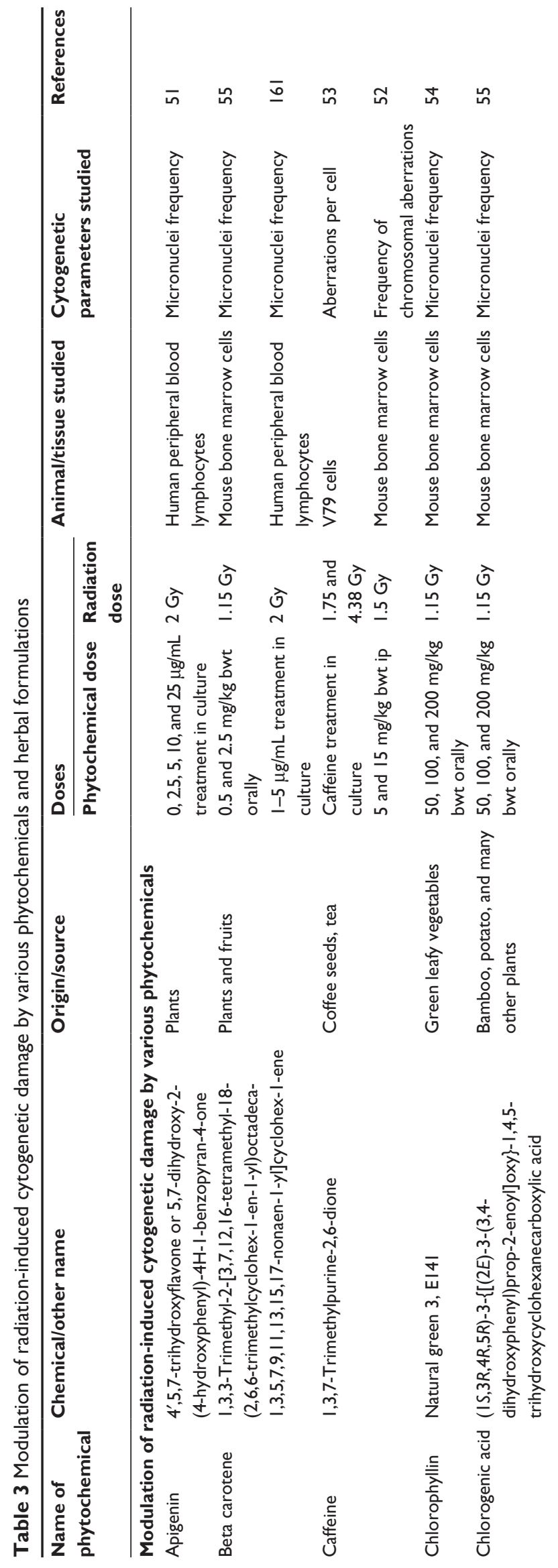




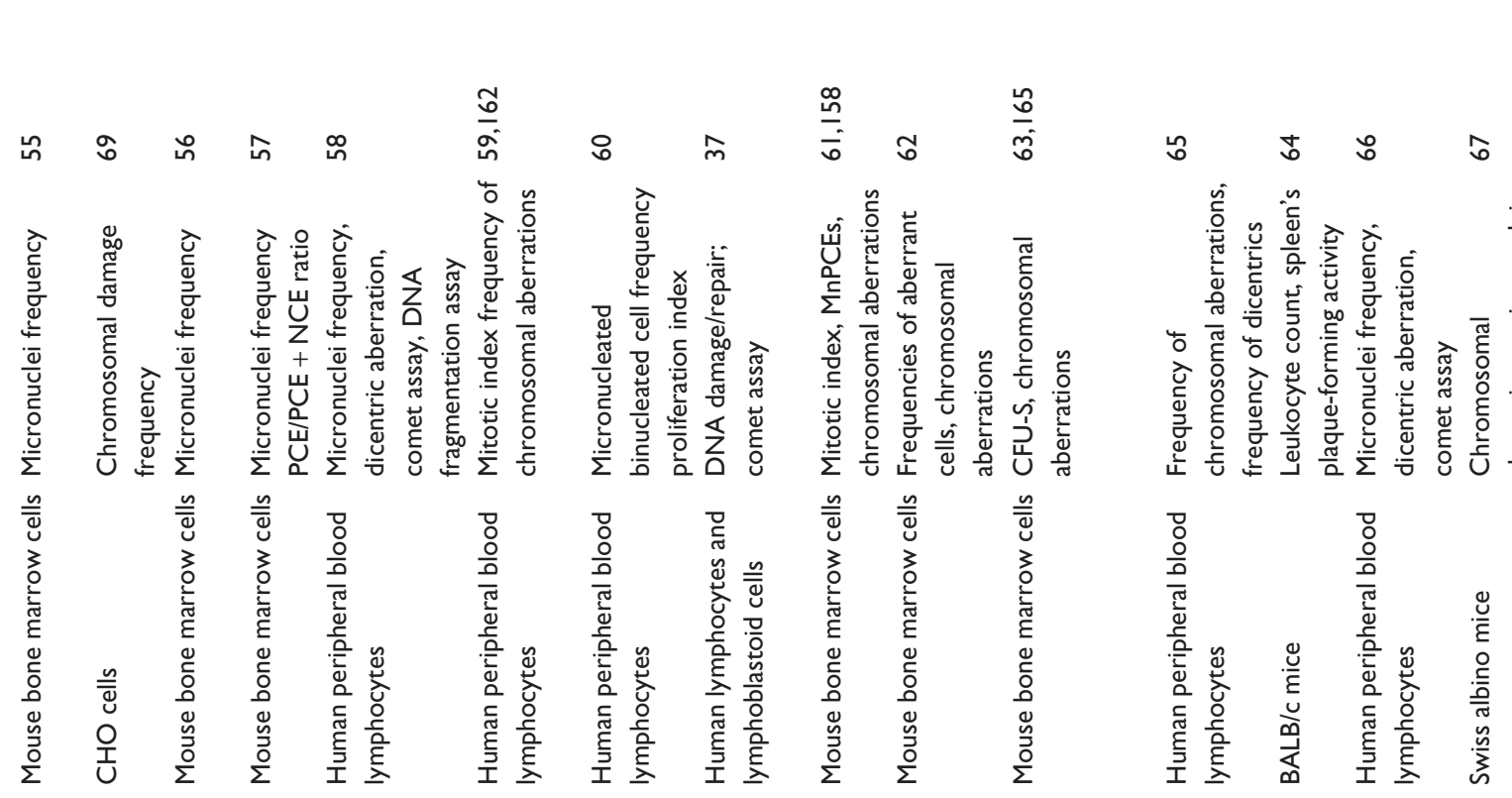

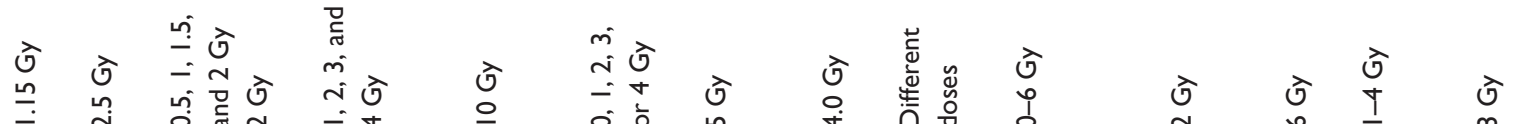

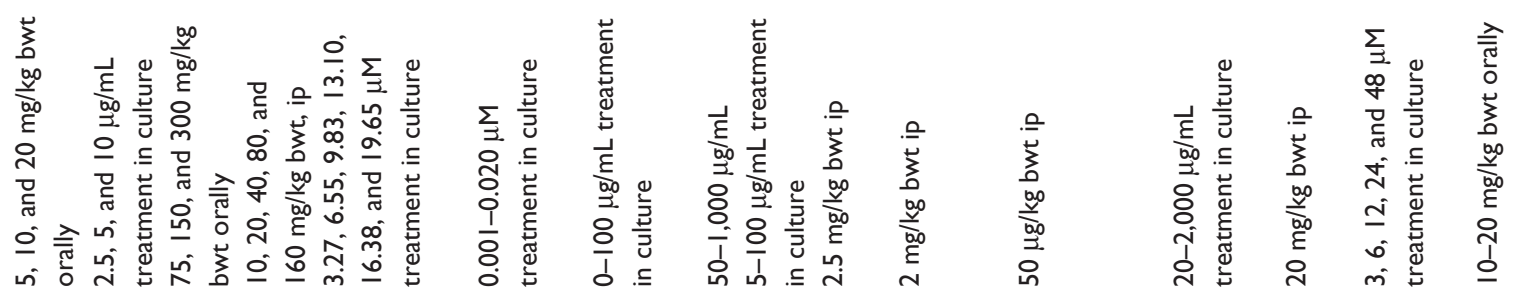

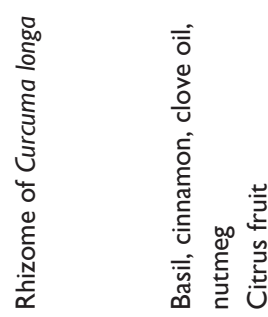
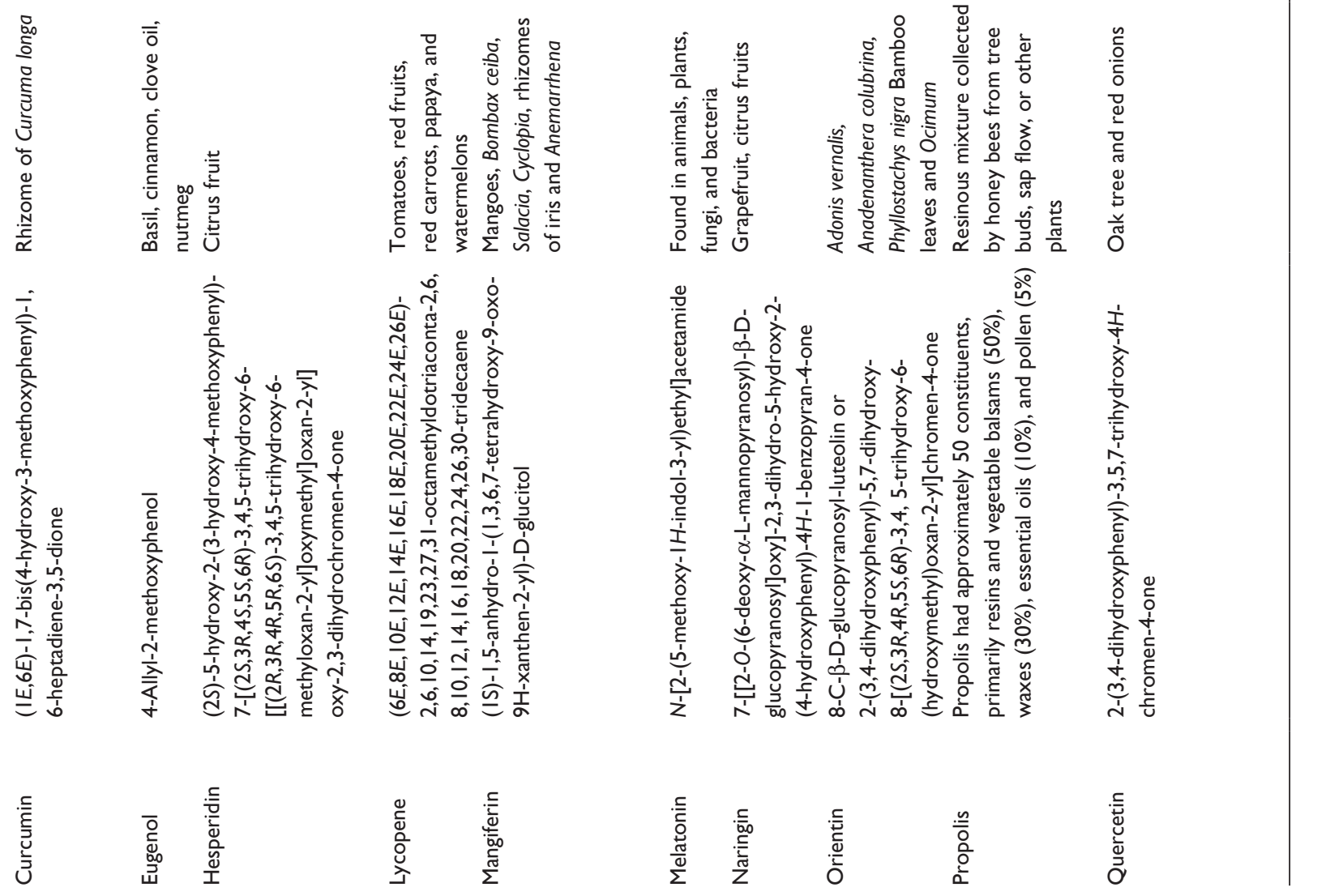


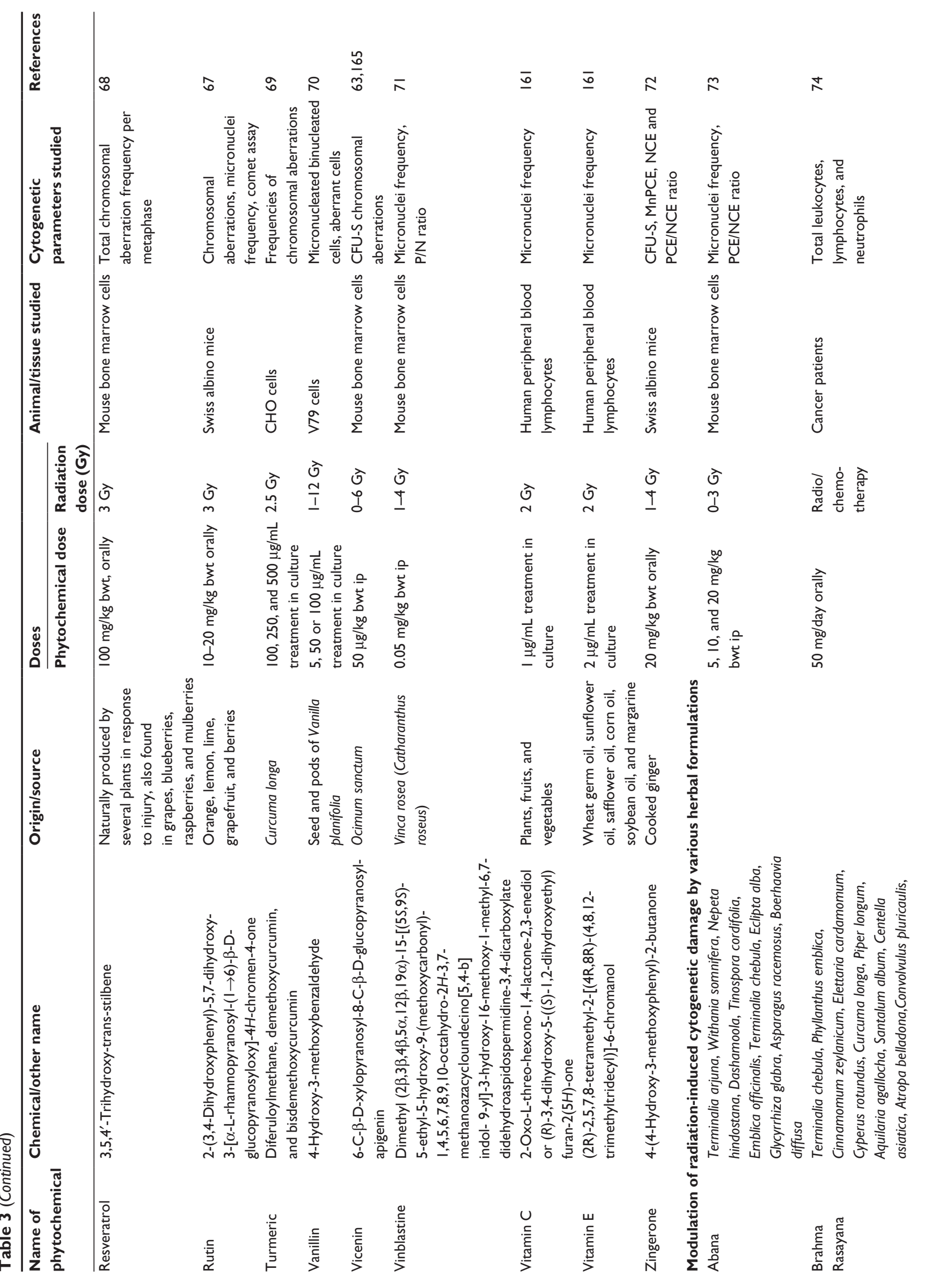




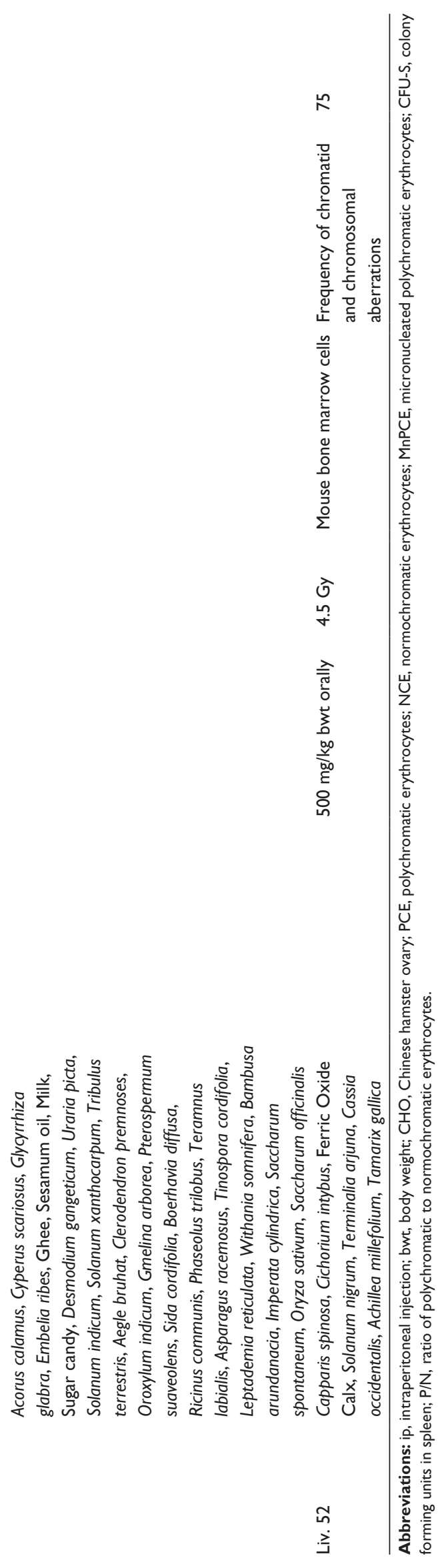

polychromatic erythrocytes (MnPCE) occurred when beta carotene was given orally to mice before radiation exposure.

\section{Caffeine}

The radioprotective property of caffeine was evaluated in mice with acute and chronic dosing as well as caffeine treatment given before or after irradiation. ${ }^{52}$ It has been reported that acute doses of caffeine before or after irradiation were responsible for a reduction in the number of chromosomal aberrations. The different doses of caffeine were also studied for cytogenetic biomarkers in Chinese hamster V79 cells. ${ }^{53}$ The various types of chromosomal aberrations were significantly decreased with caffeine treatment.

\section{Chlorogenic acid}

The radiation-induced cytogenetic damage in bone marrow of mice after chlorogenic acid administration was evaluated by micronucleus test. ${ }^{55}$ It has been demonstrated that a significant decline in the number of MnPCE occurred when chlorogenic acid was given orally to mice before radiation exposure.

\section{Chlorophyllin}

The effect of chlorophyllin was studied in mouse bone marrow using cytogenetic biomarkers to evaluate its radioprotective properties. ${ }^{54}$ Radiation-induced micronucleated polychromatic erythrocytes were found to be significantly reduced in chlorophyllin treated irradiated animals.

\section{Curcumin}

The radiation-induced cytogenetic damage in bone marrow of mice after curcumin administration was evaluated by micronucleus test. ${ }^{55,69}$ It has been demonstrated that a significant decline in the number of MnPCE occurred when curcumin was given orally to mice before radiation exposure.

\section{Eugenol}

The radiation-induced genetic damage in bone marrow of mice after eugenol administration was determined using micronucleus test. ${ }^{56}$ Eugenol was found to afford significant radioprotection through reduction in MnPCEs at postirradiation interval. It has been revealed that eugenol provides radioprotection against oxidative stress and its possible role as radioprotector has been suggested.

\section{Hesperidin}

The radioprotective effects of hesperidin using micronucleus test in irradiated mice were demonstrated. ${ }^{57,58}$ It has 
been observed that hesperidin treatment had significant radioprotective activity in terms of cytogenetic biomarkers assessed in the bone marrow of mice.

\section{Lycopene}

The radioprotective potential of lycopene was assessed by cytogenetic biomarkers. ${ }^{59,162}$ It has been reported that lycopene-supplemented lymphocytes had a lower chromosomal aberration frequency.

\section{Mangiferin}

The radioprotective effects of mangiferin were evaluated by cytogenetic biomarkers in lymphocytes ${ }^{60}$ and lymphoblastoid cells. ${ }^{37}$ The results of cytogenetic studies revealed that mangiferin has significant radioprotective potential and has the capacity to suppress radiation-induced DNA damage via free radicals in lymphocytes and lymphoblastoid cells.

\section{Melatonin}

The possible role of melatonin as radioprotector has been demonstrated through bone marrow chromosomal aberration analysis in mice. ${ }^{61,158}$ It has been observed that melatonin treatment before irradiation caused a decrease in aberrant cells as well as structural chromosomal aberrations. These cytogenetic biomarkers have provided the evidence for melatonin as radioprotector.

\section{Naringin}

Cytogenetic analysis was carried out to evaluate the radioprotective effect of naringin in mice. ${ }^{62}$ It was observed that naringin pretreatment had a protective effect on cytogenetic endpoints.

\section{Orientin}

A radioprotective study was carried out in mouse bone marrow for evaluating orientin as radioprotector. ${ }^{63}$ It was observed that pretreatment with orientin provided significant radioprotective activity in terms of DRF (1.6) based on CFU-S number. Thus it was demonstrated that orientin had protective effects against radiation-induced bone marrow damage and had great potential for protection of normal tissues during radiotherapy.

\section{Propolis}

Propolis was studied for radioprotection using cytogenetic biomarkers. ${ }^{15,64,65}$ It was noticed that the frequency of dicentrics was concentration-dependent and showed great potential in reducing the chromosomal aberration frequency. Thus, propolis had radioprotective effects probably through the enhancement of antioxidant and free radical scavenging activities.

\section{Quercetin}

Quercetin was evaluated for cytogenetic protection against radiation in plasmid DNA and lymphocytes by scoring micronuclei frequency. ${ }^{66}$ It was observed that quercetin treatment significantly decreased the micronuclei and dicentric frequencies, demonstrating the anti-genotoxic potential of quercetin.

\section{Resveratrol}

Resveratrol was evaluated for protection against irradiation using cytogenetic endpoints in mice. ${ }^{68}$ The resveratrol treatment had protective effects in vivo against irradiation in mice.

\section{Rutin}

Rutin was evaluated for protective effects against radiation damage. ${ }^{67}$ A significant decline in dicentric formation in the rutin treated group was observed, thus showing its antigenotoxic potential. It has been demonstrated that administration of rutin prior to radiation exposure decreased DNA damage significantly.

\section{Turmeric}

The protective effect of turmeric against radiation-induced cytogenetic damage was evaluated in Chinese hamster ovary cells. ${ }^{69}$ It was demonstrated that turmeric had a radiomodulatory effect in Chinese hamster ovary cells.

\section{Vanillin}

Vanillin was evaluated for cytogenetic protection against radiation in V79 cells by scoring micronuclei frequency and chromosomal aberration analysis. ${ }^{70}$ It was observed that vanillin treatment decreased the percentage of structural chromosomal aberrations and percentage of micronucleated binucleated cells, thus indicating protection against cytogenetic damage induced by X-ray.

\section{Vicenin}

The radioprotective study was performed in mouse bone marrow to elucidate vicenin as radioprotector. ${ }^{63}$ It was observed that pretreatment with orientin had significant radioprotective activity evident from DRF (1.7) value. Thus it was demonstrated that vicenin had protective effects against radiationinduced bone marrow damage and had great potential for protection of normal tissues during radiotherapy. 


\section{Vinblastine}

The cytogenetic analysis was carried out to evaluate the radioprotective effect of vinblastine in mouse bone marrow cells. ${ }^{71}$ The vinblastine pretreatment showed increased frequency of micronuclei with increasing radiation dose. It was noted that vinblastine pretreatment provided protection against cytogenetic damage induced by radiation in mice.

\section{Vitamin $\mathrm{C}$ and $\mathrm{E}$}

Pre- and post-treatment with vitamin $\mathrm{C}$ and $\mathrm{E}$ was found to be effective in protecting human lymphocytes against gamma irradiation in terms of micronuclei frequency. ${ }^{161}$ Furthermore, vitamin treatment did not show any adverse effects.

\section{Zingerone}

Zingerone was evaluated for its protective effects against radiation-induced cytogenetic damage in mice by micronucleus test. ${ }^{72}$ It has been demonstrated that zingerone had a role in protecting against cytogenetic damage in mice as evident in survival assay and CFU-S studies.

\section{Radioprotective effects of certain herbal preparations \\ Abana}

A herbal preparation, abana, was studied to evaluate the radioprotective effect in mice using micronucleus test. ${ }^{73}$ The results of the cytogenetic study revealed that pretreatment with abana had prevented radiation-generated damage in bone marrow of mice, which was evident in micronuclei frequency and ratio of polychromatic erythrocytes to normochromatic erythrocytes.

\section{Brahma Rasayana}

The hematopoietic protection effect of Brahma Rasayana on cancer patients undergoing radio/chemotherapy was demonstrated. ${ }^{74}$ It was observed that administration of Brahma Rasayana prevented the hematopoietic damage in terms of increase in total leukocytes, thus finding application as an adjuvant in cancer therapy.

\section{Liv. 52}

Cytogenetic analysis was carried out to evaluate the radioprotective effect of Liv. 52 in mouse bone marrow cells. ${ }^{75} \mathrm{It}$ was observed that Liv. 52 pretreated irradiated animals had significant recovery in cytogenetic endpoints studied.

\section{Future perspectives}

In recent years there has been a surge in the use of plant products for treatment of various illnesses including cancer.
The use of plant-based medicine has limitations in terms of systematic studies carried out for each plant product. Therefore, research must be done to acquire knowledge about the safe use of plant-based drugs before their possible use in medicine. ${ }^{76}$ Studies on pharmacokinetics and pharmacodynamic properties including toxicity are essentially needed. ${ }^{77}$ Quality control studies must focus on proper elucidation regarding evaluation process to report defined effects of the drug and factors such as age, sex, and species of the animal must also be considered. ${ }^{78}$ The damage induced by ionizing radiation in cells is modulated by various mechanisms and pathways. ${ }^{79}$ It has been suggested that radioprotectors protect cells by scavenging free radicals, or by hydrogen atom donation to repair sites of DNA damage. ${ }^{3,80}$ The deleterious effects of radiation are minimized by radioprotective agents, these agents are known to scavenge the reactive oxygen species thus preventing their immediate interaction with biochemical molecules. ${ }^{165}$ The plants have varied antioxidant capacities probably due to differences in their contents of chemical constituents thus resulting in inconsistent radioprotective effects. ${ }^{81}$ For instance, in human studies with carotenoids it was shown that carotenoids can protect against radiation but a high dose of single compound carotenoid led to high mortality. ${ }^{164}$ Several scientific studies ${ }^{16}$ have demonstrated the role of plants and phytochemicals for prevention of radiation-induced toxicity and damage thus demonstrating the significance, and demanding more attention. ${ }^{16}$ However, most of the studies have used either animal models or cell cultures and therefore, it is difficult to extend their validity in clinical settings thus causing a major limitation. ${ }^{166}$ In fact these studies throw light on the mechanism of action. Apart from applications in clinics, plants, herbal formulations, and phytochemicals may have a use in case of accidental exposure to radiation. However, considering relevance of the field of plant-based radioprotectors, plant extracts and plant-derived compounds must be stringently analyzed in different models of radiation injury.

\section{Disclosure}

The authors report no conflicts of interest in this work.

\section{References}

1. Coggle CE. Biological Effects of Radiation. 2nd ed. London: Taylor and Francis Ltd.; 1983.

2. Stark G. The effect of ionizing radiation on lipid membranes. Biochim Biophys Acta. 1991;1071(2):103-122.

3. Bump EA, Brown JM. Role of glutathione in the radiation response of mammalian cells in vitro and in vivo. Pharmacol Ther. 1990;47(1): $117-136$. 
4. Radford IR. The level of induced DNA double-strand breakage correlates with cell killing after X-irradiation. Int J Radiat Biol Relat Stud Phys Chem Med. 1985;48(1):45-54.

5. Casarett AP. Radiation Biology. Englewood Cliffs (NJ): Prentice-Hall; 1968.

6. Natarajan AT, Obe G, van Zeeland AA, Palitti F, Meijers M, VerdegaalImmerzeel EA. Molecular mechanisms involved in the production of chromosomal aberrations. II. Utilization of Neurospora endonuclease for the study of aberration production by X-rays in G1 and G2 stages of the cell cycle. Mutat Res. 1980;69(2):293-305.

7. Bryant PE. Use of restriction endonucleases to study relationships between DNA double-strand breaks, chromosomal aberrations and other end-points in mammalian cells. Int J Radiat Biol. 1988;54(6): 869-890.

8. Clancy S. DNA damage and repair: mechanisms for maintaining DNA integrity. Nat Educ. 2008;1(1):103.

9. Kamdar RP, Matsumoto Y. Radiation-induced XRCC4 association with chromatin DNA analyzed by biochemical fractionation. $J$ Radiat Res. 2010;51(3):303-313.

10. Gajski G, MilkovićD, Ranogajec-Komor M, Miljanić S, Garaj-Vrhovac V. Application of dosimetry systems and cytogenetic status of the child population exposed to diagnostic X-rays by use of the cytokinesisblock micronucleus cytome assay. J Appl Toxicol. 2011;31(7): 608-617.

11. Romm H, Oestreicher U, Kulka U. Cytogenetic damage analyzed by the dicentric assay. Ann Ist Super Sanita. 2009;45(3):251-259.

12. Blakely WF, Prasanna PG, Kolanko CJ, et al. Application of the premature chromosome condensation assay in simulated partial-body radiation exposures: evaluation of the use of an automated metaphasefinder. Stem Cells. 1995;13 Suppl 1:223-230.

13. Wu JH, Jones NJ. Assessment of DNA interstrand crosslinks using the modified alkaline comet assay. Methods Mol Biol. 2012;817: $165-181$.

14. Anglin EJ, Salisbury C, Bailey S, et al. Sorted cell microarrays as platforms for high-content informational bioassays. Lab Chip. 2010;10(24): 3413-3421.

15. Benkovic V, Horvat Knezevic A, Dikic D, et al. Radioprotective effects of propolis and quercetin in $\gamma$-irradiated mice evaluated by the alkaline comet assay. Phytomedicine. 2008;15(10):851-858.

16. Hosseinimehr SJ. Trends in the development of radioprotective agents. Drug Discov Today. 2007;12(19-20):794-805.

17. Kumar M, Samarth R, Kumar M, Selvan SR, Saharan B, Kumar A. Protective effect of Adhatoda vasica Nees against radiation-induced damage at cellular, biochemical and chromosomal levels in Swiss albino mice. Evid Based Complement Alternat Med. 2007;4(3):343-350.

18. Jagetia GC, Venkatesh P, Baliga MS. Evaluation of the radioprotective effect of Aegle marmelos (L.) Correa in cultured human peripheral blood lymphocytes exposed to different doses of gamma-radiation: a micronucleus study. Mutagenesis. 2003;18(4):387-393.

19. Jagetia GC, Venkatesh P. Inhibition of radiation-induced clastogenicity by Aegle marmelos (L.) correa in mice bone marrow exposed to different doses of gamma-radiation. Hum Exp Toxicol. 2007;26(2):111-124.

20. Jahan S, Goyal PK. Protective effect of Alstonia scholaris against radiation-induced clastogenic and biochemical alterations in mice. J Environ Pathol Toxicol Oncol. 2010;29(2):101-111.

21. Singh SP, Abraham SK, Kesavan PC. In vivo radioprotection with garlic extract. Mutat Res. 1995;345(3-4):147-153.

22. Das T, Choudhury AR, Sharma A, Talukder G. Effects of crude garlic extract on mouse chromosomes in vivo. Food Chem Toxicol. 1996;34(1):43-47.

23. Jagetia GC, Venkatesha VA. Treatment of mice with stem bark extract of Aphanamixis polystachya reduces radiation-induced chromosome damage. Int J Radiat Biol. 2006;82(3):197-209.

24. Tiku AB, Abraham SK, Kale RK. Protective effect of the cruciferous vegetable mustard leaf (Brassica campestris) against in vivo chromosomal damage and oxidative stress induced by $\gamma$-radiation and genotoxic chemicals. Environ Mol Mutagen. 2008;49(5):335-342.
25. Guruvayoorappan C, Kuttan G. Protective effect of Biophytum sensitivum (L.) DC on radiation-induced damage in mice. Immunopharmacol Immunotoxicol. 2008;30(4):815-835.

26. Karchuli MS, Ganesh N. Protective effect of Bixa orellana L. against radiation induced chromosomal aberration in Swiss albino mice. Int J Phytomed. 2009;1:18-21.

27. Hosseinimehr SJ, Tavakoli H, Pourheidari G, Sobhani A, Shafiee A. Radioprotective effects of citrus extract against gamma-irradiation in mouse bone marrow cells. J Radiat Res. 2003;44(3):237-241.

28. Rao BS, Shanbhoge R, Upadhya D, et al. Antioxidant, anticlastogenic and radioprotective effect of Coleus aromaticus on Chinese hamster fibroblast cells (V79) exposed to gamma radiation. Mutagenesis. 2006; 21(4):237-242.

29. Hosseinimehr SJ, Azadbakht M, Mousavi SM, Mahmoudzadeh A, Akhlaghpoor S. Radioprotective effects of hawthorn fruit extract against gamma irradiation in mouse bone marrow cells. J Radiat Res. 2007; 48(1):63-68.

30. Ribeiro LR, Silva AR, Bautista AR, et al. Clastogenic effect of extracts obtained from Crotalaria retusa L. and Crotalaria mucronata Desv. on mouse bone marrow cells. Mutat Res. 1993;300(3-4):253-258.

31. Rao BS, Upadhya D, Adiga SK. Protection of ionizing radiationinduced cytogenetic damage by hydroalcoholic extract of Cynodon dactylon in Chinese hamster lung fibroblast cells and human peripheral blood lymphocytes. J Environ Pathol Toxicol Oncol. 2008;27(2): 101-112.

32. Emerit I, Arutyunyan R, Oganesian N, et al. Radiation-induced clastogenic factors: anticlastogenic effect of ginkgo biloba extract. Free Radic Biol Med. 1995;18(6):985-999.

33. Popov B, Radev R, Georgieva S. In vitro incidence of chromosome aberrations in gamma-irradiated rabbit lymphocytes, treated with $H a b$ erlea rhodopensis extract and vitamin C. Bulg J Vet Med. 2010;13(3): $148-153$.

34. Popov B, Georgieva S, Gadjeva V, Petrov V. Radioprotective, anticlastogenic and antioxidant effects of total extract of Haberlea Rhodopensis on rabbit blood samples exposed to gamma radiation in vitro. Revue Méd Vét. 2011;162(1):34-39.

35. Georgieva S, Popov B, Bonev G. Radioprotective effect of Haberlea rhodopensis (Friv.) leaf extract on gamma-radiation-induced DNA damage, lipid peroxidation and antioxidant levels in rabbit blood. Indian J Exp Biol. 2013;51(1):29-36.

36. Agrawala PK, Goel HC. Protective effect of RH-3 with special reference to radiation induced micronuclei in mouse bone marrow. Indian J Exp Biol. 2002;40(5):525-530.

37. Rodeiro I, Delgado R, Garrido G. Effects of a Mangifera indica L. stem bark extract and mangiferin on radiation-induced DNA damage in human lymphocytes and lymphoblastoid cells. Cell Prolif. 2014;47(1): $48-55$.

38. Samarth RM, Kumar A. Mentha piperita (Linn.) leaf extract provides protection against radiation induced chromosomal damage in bone marrow of mice. Indian J Exp Biol. 2003;41(3):229-237.

39. Samarth RM. Protection against radiation induced hematopoietic damage in bone marrow of Swiss albino mice by Mentha piperita (Linn). J Radiat Res. 2007;48(6):523-528.

40. Rao AV, Devi PU, Kamath R. In vivo radioprotective effect of Moringa oleifera leaves. Indian J Exp Biol. 2001;39(9):858-863.

41. Duan Y, Zhang H, Xie B, et al. Whole body radioprotective activity of an acetone-water extract from the seedpod of Nelumbo nucifera Gaertn. seedpod. Food Chem Toxicol. 2010;48(12):3374-3384.

42. Rastogi L, Feroz S, Pandey BN, Jagtap A, Mishra KP. Protection against radiation-induced oxidative damage by an ethanolic extract of Nigella sativa L. Int J Radiat Biol. 2010;86(9):719-731.

43. Ganasoundari A, Devi PU, Rao MN. Protection against radiationinduced chromosome damage in mouse bone marrow by Ocimum sanctum. Mutat Res. 1997;373(2):271-276.

44. Ivanova T, Han Y, Son HJ, Yun YS, Song JY. Antimutagenic effect of polysaccharide ginsan extracted from Panax ginseng. Food Chem Toxicol. 2006;44(4):517-521. 
45. Lee TK, Wang W, O'Brien KF. Effect of North American ginseng on ${ }^{137} \mathrm{Cs}$-induced micronuclei in human lymphocytes: a comparison with WR-1065. Phytother Res. 2008;22(12):1614-1622.

46. Thakur I, Devi PU, Bigoniya P. Protection against radiation clastogenecity in mouse bone marrow by Phyllanthus niruri. Indian J Exp Biol. 2011;49(9):704-710.

47. Verma S, Gupta ML. Radiation induced hematopoietic myelosuppression and genotoxicity get significantly countered by active principles of Podophyllum hexandrum: a study in Strain 'A' mice. Int J Radiat Biol. 2015;15:1-41.

48. Dutta S, Gupta ML. Alleviation of radiation-induced genomic damage in human peripheral blood lymphocytes by active principles of Podophyllum hexandrum: an in vitro study using chromosomal and CBMN assay. Mutagenesis. 2014;29(2):139-147.

49. Ganasoundari A, Zare SM, Devi PU. Modification of bone marrow radiosensensitivity by medicinal plant extracts. Br J Radiol. 1997; 70(834):599-602.

50. Qishen P, Guo BJ, Kolman A. Radioprotective effect of extract from Spirulina platensis in mouse bone marrow cells studied by using the micronucleus test. Toxicol Lett. 1989;48(2):165-169.

51. Rithidech KN, Tungjai M, Whorton EB. Protective effect of apigenin on radiation-induced chromosomal damage in human lymphocytes. Mutat Res. 2005;585(1-2):96-104.

52. Farooqi Z, Kesavan PC. Radioprotection by caffeine pre- and posttreatment in the bone marrow chromosomes of mice given whole-body gamma-irradiation. Mutat Res. 1992;269(2):225-230.

53. Lücke-Huhle C, Hieber L, Wegner RD. Caffeine-mediated release of alpharadiation-induced $\mathrm{G} 2$ arrest increases the yield of chromosome aberrations Int J Radiat Biol Relat Stud Phys Chem Med. 1983;43(2):123-132.

54. Abraham SK, Sarma L, Kesavan PC. Role of chlorophyllin as an in vivo anticlastogen: protection against gamma-radiation and chemical clastogens. Mutat Res. 1994;322(3):209-212.

55. Abraham SK, Sarma L, Kesavan PC. Protective effects of chlorogenic acid, curcumin and beta-carotene against gamma-radiation-induced in vivo chromosomal damage. Mutat Res. 1993;303(3):109-112.

56. Tiku AB, Abraham SK, Kale RK. Eugenol as an in vivo radioprotective agent. J Radiat Res. 2004;45(3):435-440.

57. Hosseinimehr SJ, Nemati A. Radioprotective effects of hesperidin against gamma irradiation in mouse bone marrow cells. Br J Radiol 2006;79(941):415-418.

58. Kalpana KB, Devipriya N, Srinivasan M, Menon VP. Investigation of the radioprotective efficacy of hesperidin against gamma-radiation induced cellular damage in cultured human peripheral blood lymphocytes. Mutat Res. 2009;676(1-2):54-61.

59. Cavusoglu K, Yalcin E. Radioprotective effect of lycopene on chromosomal aberrations (CAs) induced by gamma radiation in human lymphocytes. J Environ Biol. 2009;30(1):113-117.

60. Jagetia GC, Venkatesha VA. Effect of mangiferin on radiation-induced micronucleus formation in cultured human peripheral blood lymphocytes. Environ Mol Mutagen. 2005;46(1):12-21.

61. Assayed ME, Abd El-Aty AM. Protection of rat chromosomes by melatonin against gamma radiation-induced damage. Mutat Res. 2009;677(1-2):14-20.

62. Jagetia GC, Venkatesha VA, Reddy TK. Naringin, a citrus flavonone, protects against radiation-induced chromosome damage in mouse bone marrow. Mutagenesis. 2003;18(4):337-343.

63. Nayak V, Devi PU. Protection of mouse bone marrow against radiation-induced chromosome damage and stem cell death by the ocimum flavonoids orientin and vicenin. Radiat Res. 2005;163(2): 165-171.

64. Scheller S, Gazda G, Krol W, et al. The ability of ethanolic extract of propolis (EEP) to protect mice against gamma irradiation. Z Naturforsch C. 1989;44(11-12):1049-1052.

65. Montoro A, Barquinero JF, Almonacid M, et al. Concentration-dependent protection by ethanol extract of propolis against $\gamma$-ray-induced chromosome damage in human blood lymphocytes. Evid Based Complement Alternat Med. 2011;2011:174853.
66. Devipriya N, Sudheer AR, Srinivasan M, Menon VP. Quercetin ameliorates gamma radiation-induced DNA damage and biochemical changes in human peripheral blood lymphocytes. Mutat Res. 2008;654(1): $1-7$.

67. Patil SL, Rao NB, Somashekarappa HM, Rajashekhar KP. Antigenotoxic potential of rutin and quercetin in Swiss mice exposed to gamma radiation. Biomed J. 2014;37(5):305-313.

68. Carsten RE, Bachand AM, Bailey SM, Ullrich RL. Resveratrol reduces radiation-induced chromosome aberration frequencies in mouse bone marrow cells. Radiat Res. 2008;169(6):633-638.

69. Araújo MC, Dias FL, Takahashi CS. Potentiation by turmeric and curcumin of gamma-radiation-induced chromosome aberrations in Chinese hamster ovary cells. Teratog Carcinog Mutagen. 1999;19(1):9-18.

70. Keshava C, Keshava N, Ong TM, Nath J. Protective effect of vanillin on radiation-induced micronuclei and chromosomal aberrations in V79 cells. Mutat Res. 1998;397(2):149-159.

71. Jagetia GC, Jacob PS. The influence of vinblastine treatment on the formation of radiation-induced micronuclei in mouse bone marrow. Hereditas. 1994;120(1):51-59.

72. Rao BN, Rao BS, Aithal BK, Kumar MR. Radiomodifying and anticlastogenic effect of Zingerone on Swiss albino mice exposed to whole body gamma radiation. Mutat Res. 2009;677(1-2):33-41.

73. Jagetia GC, Aruna R. The herbal preparation abana protects against radiation-induced micronuclei in mouse bone marrow. Mutat Res. 1997; 393(1-2):157-163.

74. Joseph CD, Praveenkumar V, Kuttan G, Kuttan R. Myeloprotective effect of a non-toxic indigenous preparation Rasayana in cancer patients receiving chemotherapy and radiation therapy. A pilot study. J Exp Clin Cancer Res. 1999;18(3):325-329.

75. Jagetia GC, Ganapathi NG. Treatment of mice with a herbal preparation (Liv. 52) reduces the frequency of radiation-induced chromosome damage in bone marrow. Mutat Res. 1991;253(2):123-126.

76. Ammon HP, Wahl MA. Pharmacology of Curcuma longa. Planta Med. 1991;57(1):1-7.

77. Kelloff GJ, Boone CW, Steele VE, Crowell JA, Lubet R, Sigman CC. Progress in cancer chemoprevention: perspectives on agent selection and short-term clinical intervention trials. Cancer Res. 1994;54 (7 Suppl):2015s-2024s.

78. Verhagen H, Aruoma OI, van Delft JH, et al. The 10 basic requirements for a scientific paper reporting antioxidant, antimutagenic or anticarcinogenic potential of test substances in vitro experiments and animal studies in vivo. Food Chem Toxicol. 2003;41(5):603-610.

79. Weiss JF, Landauer MR. Radioprotection by antioxidants. Ann NY Acad Sci. 2000;899:44-60.

80. Murray D. Aminothiols. In: Bump EA, Malaker K, editors. Radioprotectors: Chemical, Biological and Clinical Perspective. Boca Raton, FL: CRC Press; 1998:53-109.

81. Samarth RM, Panwar M, Kumar M, Soni A, Kumar M, Kumar A. Evaluation of antioxidant and radical-scavenging activity of certain radioprotective plant extracts. Food Chem. 2008;106:868-873.

82. Lushbaugh CC, Hubner KF, Fry SA. The impact of estimates of human radiation tolerance upon radiation emergency management. In: The control of exposure of the public to ionizing radiation in the event of accident or attack. Washington, DC: National Council on Radiation Protection and Measurements; 1981:46-57.

83. United Scientific Committee on the effects of Atomic Radiation. Ionizing radiation: Sources and effects. Report to the General Assembly. New York: United Nations. 1982. Available from: http://www.unscear.org/ unscear/en/publications/1982.html. Accessed September 11, 2015.

84. Mole RH. The LD50 for uniform low LET irradiation of man. $\mathrm{Br} J$ Radiol. 1984;57(677):355-369.

85. Jagetia GC. Radiation-induced chromosomal aberrations in the bone marrow of mice exposed to various doses of gamma radiation. Radiat Environ Biophys. 1993;32(2):109-117.

86. Goans RE, Holloway ME, Berger ME, Ricks RE. Early dose assessment following severe radiation accidents. Health Phys. 1997;72(4): 513-518. 
87. Dyomina EA, Pylypchuk OP. Formation peculiarities of radiationinduced aberrations of chromosomes in human cells under the modifying influence of chemical agents (comparative aspects). Probl Radiac Med Radiobiol. 2013;(18):330-337.

88. Santovito A, Cervella P, Delpero M. Increased frequency of chromosomal aberrations and sister chromatid exchanges in peripheral lymphocytes of radiology technicians chronically exposed to low levels of ionizing radiations. Environ Toxicol Pharmacol. 2014;37(1):396-403.

89. Caradonna F. Nucleoplasmic bridges and acrocentric chromosome associations as early markers of exposure to low levels of ionising radiation in occupationally exposed hospital workers. Mutagenesis. 2015;30(2):269-275.

90. Hoffmann W, Schmitz-Feuerhake I. How radiation-specific is the dicentric assay. J Expo Anal Environ Epidemiol. 1999;9(2):113-133.

91. Horneck G. Biological monitoring of radiation exposure. Adv Space Res. 1998;22(12):1631-1641.

92. Amundson SA, Bittner M, Meltzer P, Trent J, Forance AJ Jr. Biological indicators for the indication of ionizing radiation exposure in humans. Expert Rev Mol Diagn. 2001;1(2):211-219.

93. Sandgren DJ, Ledney GD. From cell to organism: the need for multiparametric assessment of exposure and biological effects. Br J Radiol. 2005;27:139-145.

94. Blakely WF, Ossetrov NI, Manglapus GL, et al. Amylase and blood cell-count hematological radiation-injury biomarkers in a rhesus monkey radiation model-use of multiparameter and integrated biological dosimetry. Radiat Meas. 2007:1164-1170.

95. Monem AS, Ali FM, Al-thani NJ, Ali SA. Membrane solubilization in erythrocytes as a measure of radiation exposure to fast neutrons. Phys Med Biol. 1999;44(2):347-355.

96. Schmid E, Bauchinge M, Bunde E, Ferbert HF, Lieven H. Comparison of the chromosome damage and its dose response after medical whole-body exposure to Co-60 gamma-rays and irradiation of blood in vitro. Int J Radiat Biol Stud Phys Chem Med. 1974;26(1):31-37.

97. Vulpis N, Tognacci L, Scarpa G. Chromosome aberration as a dosimetric technique for fission neutrons over the dose-range $0.2-50 \mathrm{rad}$. Int J Radiat Biol Relat Stud Chem Med. 1978;33(3):301-306.

98. Dolphin GW, Lloyd DC. The significance of radiation-induced chromosome abnormalities in radiological protection. J Med Genet. 1974;11(2):181-189.

99. Das BC, Sharma T. Blood lymphocyte culture system: quantitative analysis of X-ray induced chromosome aberrations in man, muntjac, and cattle. Mutat Res. 1983;110(1):111-139.

100. Hacker U, Schumann J, Gohde W. Mammalian spermatogenesis as a new system for biologic dosimetry of ionizing radiation. Acta Radiol Oncol. 1982;21(5):349-351.

101. M'kacher R, El Maalouf E, Terzoudi G, et al. Detection and automated scoring of dicentric chromosomes in nonstimulated lymphocyte prematurely condensed chromosomes after telomere and centromere staining. Int J Radiat Oncol Biol Phys. 2015;91(3):640-649.

102. Strauss GH, Albertini RJ. Enumeration of 6-thioguanine-resistant peripheral lymphocytes in man as a potential test for somatic cell mutations arising in vivo. Mutat Res. 1979;61(2):353-379.

103. Fenech M, Moley AA. Measurement of micronuclei in human lymphocytes. Mutat Res. 1985;147(1-2):29-36.

104. Singh NP, McCoy MT, Raymond R, Schneider TE. A simple technique for quantitation of low levels of DNA damage in individual cells. Exp Cell Res. 1988;175(1):184-191.

105. Messing K, Ferraris J, Bradley WE, Swartz J, Siefert AM. Mutant frequency of radiotherapy technicians appear to be associated with recent dose of ionizing radiation. Health Phys. 1989;57(4):537-544.

106. Ostrosky-Wegman P, Montero R, Palao A, Cortinos de Nava, Hutado F, Albertini RJ. 6-Thioguanine-resistant T-lymphocyte autoradiography assay. Determination of variation frequencies in individuals suspected of radiation exposure. Mutat Res. 1990;232(1):49-56.

107. Rothaman N, Stewart WF, Schlute PA. Incorporating biomarkers into cancer epidemiology: a matrix of biomarker and study design categories. Cancer Epidemiol Biomarkers Prev. 1995;4(4):301-311.
108. Lucas JN. Chromosome's translocations: a biomarker for retrospective dosimetry. Environ Health Perspect. 1997;105 Suppl 6:1433-1436.

109. Kanda R, Eguchi-Kasai K, Hayata I. Phosphatase inhibitors and premature chromosome condensation in human peripheral lymphocytes at different cell-cycle phases. Somat Cell Mol Genet. 1999;25(1):1-8.

110. d'Adda di Fagagna F, Reaper PM, Clay-Farrace L, et al. A DNA damage checkpoint response in telomere-initiated senescence. Nature. 2003;426(6963):194-198.

111. Shmakova NL, Nasonova EA, Krasavin EA, Komova OV, Mel'nikova LA, Fadeeva TA. Индукция хромосомных аберраций и микроядер в лимфоцитах периферической крови человека при низкой дозе излучения [Induction of chromosome aberrations and micronuclei in human peripheral blood lymphocytes at low dose of radiation]. Radiats Biol Radioecol. 2006;46(4):480-487. Russian.

112. Mitsuhashi M, Peel D, Ziogas A, Anton-Culver H. Enhanced expression of radiation-induced leukocyte CDKN1A mRNA in multiple primary breast cancer patients: potential new marker of cancer susceptibility. Biomark Insights. 2009;4:201-209.

113. Eken A, Aydin A, Erdem O, et al. Cytogenetic analysis of peripheral blood lymphocytes of hospital staff occupationally exposed to low doses of ionizing radiation. Toxicol Ind Health. 2010;26(5):273-380.

114. Wolff HA, Hennies S, Herrmann MK, et al. Comparison of the micronucleus and chromosome aberration techniques for the documentation of cytogenetic damage in radiochemotherapy-treated patients with rectal cancer. Strahlenther Onkol. 2011;187(1):52-58.

115. Vral A, Fenech M, Thierens $H$. The micronucleus assay as a biological dosimeter of in vivo ionising radiation exposure. Mutagenesis. 2011; 26(1):11-17.

116. Chen Y, Zhou PK, Zhang XQ, Wang ZD, Wang Y, Darroudi F. Cytogenetic studies for a group of people living in Japan 1 year after the Fukushima nuclear accident. Radiat Prot Dosimetry. 2014;159(1-4): 20-25.

117. Huumonen K, Korkalainen M, Boman E, et al. Dose- and timedependent changes of micronucleus frequency and gene expression in the progeny of irradiated cells: two components in radiation-induced genomic instability? Mutat Res. 2014;765:32-39.

118. Littlefield LG, Colyer SP, Joiner EE, DuFrain RJ. Sister chromatid exchanges in human lymphocytes exposed to ionizing radiation during $\mathrm{G}_{0}$. Radiat Res. 1979;78(3):514-521.

119. Brooks AL, Khan MA, Jostes RF, Cross FT. Metaphase chromosome aberrations as markers of radiation exposure and dose. J Toxicol Environ Health. 1993;40(2-3):277-288.

120. Collins AR, Dusinska M, Gedik CM, Stetina R. Oxidative damage to DNA: do we have a reliable biomarker? Environ Health Perspect. 1996;104 Suppl 3:465-469.

121. Spruill MD, Ramsey MJ, Swiger RR, Nath J, Tucker JD. The persistence of aberrations in mice induced by gamma radiation as measured by chromosome painting. Mutat Res. 1996;356(2):135-145.

122. Darroudi F, Fomina J, Meijers M, Natarajan AT. Kinetics of the formation of chromosome aberrations in X-irradiated human lymphocytes, using PCC and FISH. Mutat Res. 1998;404(1-2):55-65.

123. Gaba C, Kushner I. Acute-phase proteins and other systemic response to inflammation. N Engl J Med. 1999;340(6):448-454.

124. Guipaud O, Holler V, Buard V, et al. Time-course analysis of mouse serum proteome changes following exposure of the skin to ionizing radiation. Proteomics. 2007;7(21):3992-4002.

125. Wu Jie, Yan Y, Yan, F, Ju H. Electric field-driven strategy for multiplexed detection of protein biomarkers using a disposable reagentless electrochemical immunosensor array. Anal Chem. 2008;80(15): 6072-6077.

126. Carr SA, Anderson L. Protein quantitation through targeted mass spectrometry: the way out of biomarker purgatory? Clin Chem. 2008; 54(11):1749-1752.

127. Little MP, Kwon D, Doi K, et al. Association of chromosome translocation rate with low dose occupational radiation exposures in U.S. radiologic technologists. Radiat Res. 2014;182(1):1-17. 
128. Lv LL, Liu BC. High-throughput antibody microarrays for quantitative proteomic analysis. Expert Rev Proteomics. 2007;4(4):505-513.

129. Ossetrova NI, Blakely WF. Multiple blood-proteins approach for early-response exposure assessment using an in vivo murine radiation model. Int J Radiat Biol. 2009;85(10):837-850.

130. Weinrich D, Christof P, Niemeyer M, Waldmann H. Applications of protein biochips in biomedical and biotechnological research. Angew Chem Int Ed Engl. 2009;484(42):7744-7751.

131. Weinrich D, Jonkheijm P, Niemeyer CM, Waldmann H. Proteinbiochips in der Biomedizin und Biotechnologie [Protein biochips in biomedicine and biotechnology]. Angew Chem. 2009;121(2): 7880-7888. German.

132. Bayts A, Grant SG. Neuroproteomics: understanding the molecular organization and complexity of the brain. Nat Rev Neurosci. 2009; 10(9):635-646.

133. Balakrishnan S, Shirsath K, Bhat N, Anjaria K. Biodosimetry for high dose accidental exposures by drug induced premature chromosome condensation (PCC) assay. Mutat Res. 2010;699(1-2):11-16.

134. Miura T, Blakely WF. Optimization of calyculin A-induced premature chromosome condensation assay for chromosome aberration studies Cytometry A. 2011;79(12):1016-1022.

135. Puig R, Barrios L, Pujol M, Caballín MR, Barquinero JF. Suitability of scoring PCC rings and fragments for dose assessment after high-dose exposures to ionizing radiation. Mutat Res. 2013;757(1):1-7.

136. Pathak R, Prasanna PG. Premature chromosome condensation in human resting peripheral blood lymphocytes without mitogen stimulation for chromosome aberration analysis using specific whole chromosome DNA hybridization probes. Methods Mol Biol. 2014;1105:171-181.

137. González JE, Romero I, Gregoire E, et al. Biodosimetry estimation using the ratio of the longest: shortest length in the premature chromosome condensation (PCC) method applying autocapture and automatic image analysis. J Radiat Res. 2014;55(5):862-865

138. Suto Y, Gotoh T, Noda T, et al. Assessing the applicability of FISHbased prematurely condensed dicentric chromosome assay in triage biodosimetry. Health Phys. 2015;108(3):371-376.

139. Romero I, Lamadrid AI, González JE, García O, Voisin P, Roy L. Shortening the culture time in cytogenetic dosimetry using PCC-R assay. Radiat Prot Dosimetry. 2015;163(4):424-429.

140. Gotoh E. Drug-induced premature chromosome condensation (PCC) protocols: cytogenetic approaches in mitotic chromosome and interphase chromatin. Methods Mol Biol. 2015;1288:53-66.

141. Hada M, Wu H, Cucinotta FA. mBAND analysis for high- and lowLET radiation-induced chromosome aberrations: a review. Mutat Res. 2011;711(1-2):187-192.

142. Mackinnon RN, Chudoba I. The use of M-FISH and M-BAND to define chromosome abnormalities. Methods Mol Biol. 2011;730:203-218.

143. Someya M, Sakata K, Matsumoto Y, Tauchi H, Narimatsu H, Hareyama M. Association of DNA-PK activity and radiation-induced NBS1 foci formation in lymphocytes with clinical malignancy in breast cancer patients. Oncol Rep. 2007;18(4):873-878

144. Hosing AS, Valerie NC, Dziegielewski J, Brautigan DL, Larner JM. PP6 regulatory subunit R1 is bidentate anchor for targeting protein phosphatase-6 to DNA-dependent protein kinase. J Biol Chem. 2012;287(12):9230-9239.

145. Lin YF, Nagasawa H, Little JB, et al. Differential radiosensitivity phenotypes of DNA-PKcs mutations affecting NHEJ and HRR systems following irradiation with gamma-rays or very low fluences of alpha particles. PLoS One. 2014;9(4):e93579.

146. Gustafsson AS, Abramenkovs A, Stenerlöw B. Suppression of DNAdependent protein kinase sensitize cells to radiation without affecting DSB repair. Mutat Res. 2014;769:1-10.

147. Jette N, Lees-Miller SP. The DNA-dependent protein kinase: a multifunctional protein kinase with roles in DNA double strand break repair and mitosis. Prog Biophys Mol Biol. 2015;117(2-3):194-205.
148. Nakamura H. hTERT-immortalized cells useful for analyzing effects of low-dose-rate radiation on human cells. J Radiat Res. 2008;49(1): 9-15.

149. Glaviano A, Mothersill C, Case CP, Rubio MA, Newson R, Lyng F. Effects of hTERT on genomic instability caused by either metal or radiation or combined exposure. Mutagenesis. 2009;24(1):25-33.

150. Marcon F, Siniscalchi E, Crebelli R, et al. Diet-related telomere shortening and chromosome stability. Mutagenesis. 2012;27(1): 49-57.

151. Li P, Hou M, Lou F, Björkholm M, Xu D. Telomere dysfunction induced by chemotherapeutic agents and radiation in normal human cells. Int J Biochem Cell Biol. 2012;44(9):1531-1540.

152. Thomas P, Fenech M. Cytokinesis-block micronucleus cytome assay in lymphocytes. Methods Mol Biol. 2011;682:217-234.

153. Coşkun M, Cayır A, Coşkun M, Tok H. Evaluation of background DNA damage in a Turkish population measured by means of the cytokinesisblock micronucleus cytome assay. Mutat Res. 2013;757(1):23-27.

154. François M, Hochstenbach K, Leifert W, Fenech MF. Automation of the cytokinesis-block micronucleus cytome assay by laser scanning cytometry and its potential application in radiation biodosimetry. Biotechniques. 2014;57(6):309-312.

155. Lee SL, Thomas P, Hecker J, Faunt J, Fenech M. Chromosomal DNA damage measured using the cytokinesis-block micronucleus cytome assay is significantly associated with cognitive impairment in South Australians. Environ Mol Mutagen. 2015;56(1):32-40.

156. Georgakilas AG, Holt SM, Hair JM, Loftin CW. Measurement of oxidatively-induced clustered DNA lesions using a novel adaptation of single cell gel electrophoresis (comet assay). Curr Protoc Cell Biol. 2010;6(6):11.

157. Kadam SB, Shyama SK, Almeida VG. Evaluation of the in vivo genotoxic effects of gamma radiation on the peripheral blood leukocytes of head and neck cancer patients undergoing radiotherapy. Mutat Res. 2013;752(1-2):42-46.

158. Vijayalaxmi, Reiter BRJ, Meltz ML. Melatonin protects human blood lymphocytes from radiation-induced chromosome damage. Mutat Res. 1995;346(1):23-31.

159. Rana S, Kumar R, Sultana S, Sharma RK. Radiation-induced biomarkers for the detection and assessment of absorbed radiation doses. J Pharm Bioallied Sci. 2010;2(3):189-196.

160. Terzoudi GI, Pantelias GE. Cytogenetic methods for biodosimetry and risk individualisation after exposure to ionising radiation. Radiat Prot Dosimetry. 2006;122(1-4):513-520.

161. Konopacka M, Rzeszowska-Wolny J. Antioxidant vitamins C, E and beta-carotene reduce DNA damage before as well as after gamma-ray irradiation of human lymphocytes in vitro. Mutat Res. 2001;491(1-2): $1-7$.

162. Gajowik A, Dobrzyńska MM. Lycopene - antioxidant with radioprotective and anticancer properties. A review. Rocz Panstw Zakl Hig. 2014;65(4):263-271

163. Kurabe T, Itoh Y, Matsumura E, Nakamura A, Ayakawa Y. [Radioprotective effects of natural beta-carotene on villi and crypts in abdominally radiated mice]. Nihon Igaku Hoshasen Gakkai Zasshi. 2002;62(14):822-831. Japanese.

164. Darvin M, Zastrow L, Sterry W, Lademann J. Effect of supplemented and topically applied antioxidant substances on human tissue. Skin Pharmacol Physiol. 2006;19(5):238-247.

165. Uma Devi P, Ganasoundari A, Vrinda B, Srinivasan KK, Unnikrishnan MK. Radiation protection by the ocimum flavonoids orientin and vicenin: mechanisms of action. Radiat Res. 2000;154(4) $455-460$.

166. Arora R, Gupta D, Chawla R, et al. Radioprotection by plant products: present status and future prospects. Phytother Res. 2005;19(1): $1-22$. 


\section{Publish your work in this journal}

Drug Design, Development and Therapy is an international, peerreviewed open-access journal that spans the spectrum of drug design and development through to clinical applications. Clinical outcomes, patient safety, and programs for the development and effective, safe, and sustained use of medicines are a feature of the journal, which

has also been accepted for indexing on PubMed Central. The manuscript management system is completely online and includes a very quick and fair peer-review system, which is all easy to use. Visit http://www.dovepress.com/testimonials.php to read real quotes from published authors.

Submit your manuscript here: http://www.dovepress.com/drug-design-development-and-therapy-journal 